\title{
INTEGRAL ESTIMATE OF THE EFFECTIVENESS OF PERFORMANCE OF INDICES OF STATE TARGET PROGRAMS FOR THE PROTECTION OF THE NATURAL ENVIRONMENT IN UKRAINE
}

\author{
Oksana Senyshyn' ${ }^{1}$, Nataliya Chopko², Iryna Zhuk ${ }^{3}$ \\ Ivan Franko National University of Lviv, Ukraine
}

\begin{abstract}
This scientific article deals with the integral estimate of the effectiveness of performance of indices of the state target programs for protection of the natural environment in Ukraine, namely - the subject of the research is quantitative indices of the State target program "Forests of Ukraine" for 2010-2015 and their estimate. Methodology. The methodological basis of the study is the system of indices for the estimate of effectiveness and performance of the state target programs for the protection of the natural environment that include the following indices (indicators): an integrated index of financing the program actions and indicators of co-financing. The author applies integrated indicator of financing the program tasks and actions to assess the actual level of financing the program from various sources through the entire period of the program implementation and to carry out a comparative analysis of financial support for various programs implemented at the expense of the budgetary funds and other sources. The author uses indicator of co-financing for calculating the ratio of actual and planned indicators of the attraction of the funds from other sources (public borrowings, extrabudgetary funds) per $1 \mathrm{UAH}$ of the budget funds. Results. Proceeding from the analysis of quantitative indices of the State target program "Forests of Ukraine" for 2010-2015, it was established that for all 5 years of activity, the planned level of budget financing of the Program has not been achieved. In particular, in 2010-2011, operations and tasks of the Program had been financed from the budget funds by $77 \%$ and in $2014-2015$ by 33\% and 27\% respectively. During the entire period of the Program implementation, the average annual rate of actual financing from all sources attained $147 \%$, including $53 \%$ from the state budget and $206 \%$ from other sources of financing. The author has proved that the said indices of the performance of the Program's operations remain to be at a high level $\bar{R}_{2}{ }^{6}=70$. Practical application. The author has come to the conclusion that the calculated indicator of co-financing of the State target program "Forests of Ukraine" can be used for the approval of managerial decisions on the assessment of performance of the public contracting authority in terms of attraction of funds from the local budgets and extrabudgetary funds as an important component of organization of the program implementation process. Value of the study results. Application of multidimensional quantitative indices in the process of assessment of effectiveness of the State Target Program "Forests of Ukraine" that, according to the developed algorithm, are calculated proceeding from their numerous parameters, provided the possibility to assess the combined impact of different effects by way of constructing a single quantitatively determined integral parameter for the program - the performance index.
\end{abstract}

Key words: comprehensive program of natural environmental protection, programming, level of financing, performance, effectiveness, integrated indicator of financing program activities, indicator of co-financing.

JEL Classification: Q56, H 53, C3

\footnotetext{
Corresponding author:

${ }^{1}$ Department of Management, Ivan Franko National University of Lviv.

E-mail: Okssenyshyn@gmail.com

${ }^{2}$ Department of Management, Ivan Franko National University of Lviv.

E-mail: chopko_n@yahoo.com

${ }^{3}$ Department of Tourism, Ivan Franko National University of Lviv.

E-mail: zhukiryna0312@gmail.com
} 


\section{Formulation of the problem}

State target programs for the protection of natural environment appear to be the instrument for the implementation of national environmental policy with the aid of specific program guidelines, measures, tasks, target projects with various mechanisms of their realization. The potential of international, national, and nationwide ecological programs is a lot greater with a more perfectly determined mechanism of management.

Issues of the use of the mechanism of the state target programs and assessment of their effectiveness in the economy of Ukraine were considered in the scientific research works of such scientists-economists as V. M. Heiets (2008), L. S. Hryniv (2010), B. M. Danylyshyn (2008), O. S. Zarzhytskyi (2012), L. H. Melnyk (2003), T. O. Moshchytska (2010), O. V. Faichuk (2015), L. M. Yakushenko (2015), L. D. Yatsenko (2015) and others.

The objective of the article is to estimate the effectiveness of using budget funds of the State target program "Forests of Ukraine" for 2010-2015 through the prism of determination of integral indicators, namely: an integrated indicator of financing the program operations and the indicator of co-financing.

\section{Regulatory protection of the natural environment in Ukraine}

In order to implement an effective state policy of protection of natural environment, rational use and reproduction of natural resources in Ukraine in the period of 2010-2016, the following state programs of protection of the natural environment are being implemented:

1. Nationwide target program "Drinking Water of Ukraine” for 2011-2020 (Verkhovna Rada Ukrainy, 2011).

2. State target ecological program for monitoring natural environment (Kabinet Ministriv Ukrainy, 2007).

3. Nationwide program of development of the mineral-raw materials base of Ukraine for the period up to 2030 (Verkhovna Rada Ukrainy, 2011).

4. State target program "Forests of Ukraine" for 20102015 (Kabinet Ministriv Ukrainy, 2009).

5. Nationwide target ecological program of radioactive waste materials management (Verkhovna Rada Ukrainy, 2008).

6. State target ecological program of development of the Crimea ("Ecologically Safe Crimea") for 20112015 (Kabinet Ministriv Ukrainy, 2011).

7. Nationwide target program of water economy development and ecological rehabilitation of the Dnipro river basin in the period up till 2021 (Verkhovna Rada Ukrainy, 2012).

8. Nationwide program of the formation of the national ecological network of Ukraine for 2000-2015 (Verkhovna Rada Ukrainy, 2000).
In order to carry out an effective state policy of protection of the natural environment, rational use, and reproduction of forest resources in Ukraine, the State target program "Forests of Ukraine" for 2010-2015 was developed and approved by the Decree of the Cabinet of Ministers of Ukraine № 977 of September 16, 2009 (Kabinet Ministriv Ukrainy, 2009). Elaboration of this Program was predetermined by the international commitments of Ukraine signed on the Resolution of the 4th Ministerial Conference on Protection of Forests of Europe "Strengthening of interaction in sustainable forest management in Europe through the interdepartmental collaboration and national forest programs".

\section{Estimation of complex economic effectiveness of the State Target Program "Forests of Ukraine"}

The system of quantitative indices of the State Target Program "Forests of Ukraine" for 2010-2015 (hereinafter referred to as the "Program") is used to assess the effectiveness of using budget funds, particularly, from the state borrowings (Kabinet Ministriv Ukrainy, 2009). It should be noted that economic effectiveness of the Program can be estimated provided that the estimated activity has the clearly defined objectives, tasks, and the end result. Subsequently, it will be possible to correlate the costs incurred with the achieved result and, thereafter, estimate the economic effectiveness of the works carried out. As a rule, the question of estimating the complex economic effectiveness of a particular activity is raised in case of implementation of the program activities, particularly, of the state target programs for the protection of the natural environment (STP PNE) (Ministerstvo ekonomiky Ukrainy, 2010).

Determination of the effectiveness of the STP PNE in general and by its stages is based on the use of a system of indices (indicators) that are calculated as a ratio of actual and planned indices of the program tasks accomplishment and ensure, taking into account deviations of these indices, decision-making based on the assessment of the degree of achievement of the established program goals and the planned effectiveness of spending the funds. Comparison of actual indices of STP PNE with the planned indices (approved by the program) is made by way of:

- estimation of expenses from the state budget and other sources for carrying out the program's activities and execution of its tasks (indices of expenditures);

- assessment of the degree of accomplishment of the intermediate and end goals of the program implementation using indices of the volume of the works performed and services rendered in the result of the program tasks and activities accomplishment (product index); 
- determination of the degree of achievement of quality parameters of the performed works and services rendered (indices of quality);

- assessment of cost-effectiveness of the resources used for the execution of the program tasks (indices of effectiveness);

- assessment of the level of attraction of funds from the budget and extrabudgetary sources and their ratio (co-financing indicators).

Taking into account the above said, the system of indices for the assessment of the effectiveness and performance of the STP PNE must include the following criteria and indices (indicators): an integrated index of financing the program activities and the indicator (index) of co-financing.

\section{Indicators of estimation of economic effectiveness of the state target program}

Integrated index of financing of the program activities and tasks is calculated for the assessment of the actual level of financing of the program from various sources throughout the entire period of the program implementation (or in the preceding year), as well as for carrying out the comparative analysis of the financial support for various programs implemented with financing from the budget and other sources.

Integrated index of financing activities of the target program in the $t$-th year $\left(\bar{K}^{t}\right)$ or in the period from the beginning of implementation ( $\bar{K}$, including the $l$-th year) is determined as the weighted average of indicators of the actual level of financing from the state budget and other sources (local budgets and extrabudgetary funds), calculated separately for each year provided that the sum of the weight values of indices of the actual level of financing from various sources during the period of implementation of the program is equal to 1 , and the weight of index of financing from other sources exceeds the corresponding coefficient of budget funds (Ministerstvo ekonomiky Ukrainy, 2010):

- in the year

$$
K^{t}=h \cdot \frac{C_{\phi}^{t}}{C_{\pi n}^{t}}+q \cdot \frac{V_{\phi}^{t}}{V_{n \pi}^{t}}, g>h, \text { для } t=1, \ldots, l, \ldots n ; H+q=1 ;
$$

- $\quad$ in the period in general, including the 1-th year

$$
\begin{aligned}
& \bar{K}^{\prime}=\frac{1}{l} \cdot\left[h \cdot \sum_{t=1}^{l} \frac{C_{\phi}^{t}}{C_{n n}^{t}}+q \cdot \sum_{t=1}^{l} \frac{V_{\phi}^{t}}{V_{n n}^{t}}\right] \\
& \text { для } I=2, \ldots, n ; \frac{h+q}{l}=1, q>h,
\end{aligned}
$$

where $C_{\phi}{ }^{t}, C_{n \wedge}{ }^{t}-$ actual and planned (according to the approved program) volumes of financing the program from the state budget in the $t$-th year of implementation of the program respectively; $V_{\phi}^{t}$, $V_{n t}{ }^{t}-$ actual and planned (according to the approved program) volumes of financing the program from other sources (extrabudgetary funds) in the $t$-th year of implementation of the program respectively; $n$ - number of years of the period of the program implementation.
For the calculations $\mathrm{q}=0,54, \mathrm{~h}=0,46$.

Index of the performance of the STP PNE shows the summary estimate of the performance of the budget spending intended for the execution of program activities aimed at the achievement of the established intermediate or end goals throughout the period preceding the $t$-th year or in a separate year. This index is calculated (Ministerstvo ekonomiky Ukrainy, 2010):

- in the year

$$
\begin{aligned}
& R^{t}=K^{t} \cdot\left(\frac{1}{P} \sum_{p=1}^{P} \frac{Z_{\phi(p)}^{t}}{Z_{n \pi(p)}^{t}}\right) \cdot\left(\frac{1}{M} \sum_{m=1}^{M} \frac{E_{\phi(m)}^{t}}{E_{n \pi(m)}^{t}}\right) \cdot\left(\frac{1}{G} \sum_{g=1}^{G} \frac{Q_{\phi(g)}^{t}}{Q_{n \pi(g)}^{t}}\right) \\
& \text { для } t=1, \ldots, I, \ldots, n,
\end{aligned}
$$

where $R^{t}$ - integrated index characterizing performance of the program in the $t$-th year.

- in the period of the program implementation including the $l$-th year

$$
\bar{R}^{\prime}=\frac{\bar{K}^{\prime}}{l}\left(\frac{1}{P} \sum_{t=1}^{I} \sum_{p=1}^{P} \frac{Z_{\phi(p)}^{t}}{Z_{n n(p)}^{t}}\right)\left(\frac{1}{M} \sum_{t=1}^{I} \sum_{m=1}^{M} \frac{E_{\phi(m)}^{t}}{E_{n n(m)}^{t}}\right)\left(\frac{1}{G} \sum_{t=1}^{I} \sum_{g=1}^{G} \frac{Q_{\phi(g)}^{t}}{Q_{n n(g)}^{t}}\right)
$$

для $I=2, \ldots, n$,

where $\bar{R}^{t} \quad-$ integrated index characterizing summarized performance of the program in the years of implementation preceding the $l$-th year (including the $l$-th year); $E_{\phi(m)}^{t}, E_{n \wedge}^{t}(m)-$ actual and planned indices of economic effectiveness respectively, characterizing economic effect by the ratio of the obtained results (product indices) and expenditures of budgetary and other funds (that predetermined development of this product) by the $m$-th parameters of the economic effect formation in the $t$-th year; $Z_{\phi(p)}^{t}, Z_{n \wedge(p)}^{t}$ - actual and planned (according to the approved program) respectively volumes of the executed works or manufactured products, rendered services (product indices) characterizing the result of execution of the program in the $t$-th year by the $p$-th parameter of the involved product components $(p=1, \ldots P) ; Q_{\phi(q)}^{t}, Q_{n(q)}^{t}-$ actual and planned (envisaged by the program) respectively indices characterizing quantitative parameters of the quality of executed works, manufactured products (or rendered services) depending on the results of execution of the program in the $t$-th year by the $g$-th parameter of the quality parameter $(g=1, \ldots, G)$.

Indicator (index) of co-financing - is calculated through the ratio of actual and planned indices of the attraction of funds from other sources (state borrowings, extrabudgetary funds) per $1 \mathrm{UAH}$ of budget funds and determined from the formulas (Ministerstvo ekonomiky Ukrainy, 2010):

- in the year

$$
D^{t}=\frac{V_{\phi}^{t} / \dot{C}_{\phi}^{t}}{V_{n \pi}^{t} / C_{n \pi}^{t}}=\frac{V_{\phi}^{t} \cdot C_{n n}^{t}}{V_{n \pi}^{t} \cdot C_{\phi}^{t}} \text {, для } t=1, \ldots, n,
$$

- in the period of implementation of the program (including the $l$-th year)

$$
\overline{D^{\prime}}=\frac{1}{l} \cdot \sum_{t=1}^{l} D^{t}, \text { для } I=2, \ldots, n,
$$

where $D^{t}$ - the ratio of actual and planned indices of attraction of funds from other sources (extrabudgetary 
funds) per $1 \mathrm{UAH}$ of the state in the $t$-th year; $\bar{D}^{l}-$ average annual index of attraction of funds from other sources per $1 \mathrm{UAH}$ of the state budget funds in the period of implementation of the program (including the $t$-th year).

The program co-financing indicator must be used in decision-making to assess the performance of the public contracting authority in terms of attracting funds from the local budgets and extrabudgetary funds (other sources of financing) as an important component of the organization of the program process.

\section{Results of estimation of complex economic effectiveness}

Let us consider economic results of the use of the system of integral indices on the example of implementation of the State Target Program "Forests of Ukraine" for 2010-2015 (Table 1). Indices of the Program's effectiveness have deteriorated: on the average, the planned level of spending per 1 thousand hectares of hunting lands connected with protection and reproduction of hunting animals was exceeded by $60 \%$, spending per 1 hour of aerial surveillance for the protection of forests from fires, rental of helicopters, and establishment of special platforms was exceeded by $71 \%$, spending for the forests shaping and rehabilitation per 1 hectare was exceeded by $134 \%$.

The Program's quality index "Survival of forest species" in 2010-2015 was maintained at a high level $(94.1 \%-97.7 \%)$. Of the three product indices selected for the study in the analysed period (2010-2015), only one index reached the planned level of financing (Table 2). This became possible owing to a considerable overrun of actual spending on the planned spending from other sources of financing. The average annual

Table 1

Estimate of an integrated assessment of the performance of the State Target Program "Forests of Ukraine" for 2010-2015

\begin{tabular}{|c|c|c|c|c|c|c|c|c|c|c|c|}
\hline \multirow[b]{2}{*}{ Name of index } & \multirow[b]{2}{*}{ Symbol } & \multirow[b]{2}{*}{$\mathrm{U} / \mathrm{M}$} & \multicolumn{3}{|c|}{2010} & \multicolumn{3}{|c|}{2011} & \multicolumn{3}{|c|}{2012} \\
\hline & & & planned & actual & $\begin{array}{c}\% \\
\begin{array}{c}\% \\
\text { executed }\end{array}\end{array}$ & planned & actual & $\begin{array}{c}\% \\
\text { executed }\end{array}$ & planned & actual & $\begin{array}{c}\% \\
\text { executed }\end{array}$ \\
\hline \multicolumn{12}{|c|}{ Input information } \\
\hline \multicolumn{12}{|l|}{ Financial support } \\
\hline Total & & $\begin{array}{l}\mathrm{mln} \\
\mathrm{UAH}\end{array}$ & 1641,01 & 1806,10 & $110,1 \%$ & 1854,98 & 2312,73 & $124,7 \%$ & 2036,80 & 2558,70 & $125,6 \%$ \\
\hline from state budget & $C(t)$ & $\begin{array}{l}\mathrm{mln} \\
\mathrm{UAH}\end{array}$ & 585,58 & 458,41 & $78,3 \%$ & 751,73 & 538,46 & $71,63 \%$ & 871,95 & 564,3596 & $64,72 \%$ \\
\hline $\begin{array}{l}\text { from other sources (own funds of } \\
\text { forest users) }\end{array}$ & $V(t)$ & $\begin{array}{l}\mathrm{mln} \\
\mathrm{UAH}\end{array}$ & 1055,43 & 1347,69 & $127,7 \%$ & 1103,25 & 1774,26 & $160,82 \%$ & 1164,85 & 1994,338 & $171,21 \%$ \\
\hline \multicolumn{12}{|l|}{ Product indices } \\
\hline $\begin{array}{l}\text { Forestation area (forest planting } \\
\text { and seeding) }\end{array}$ & $\mathrm{Z}(\mathrm{t}) 1$ & $\begin{array}{l}\text { thou } \\
\text { UAH }\end{array}$ & 28,7 & 27 & $94 \%$ & 52,3 & 22,6 & $43,21 \%$ & 62,4 & 18,2 & $29,17 \%$ \\
\hline $\begin{array}{l}\text { Tending forest species (area of } \\
\text { forests shaping and rehabilitation) }\end{array}$ & $\mathrm{Z}(\mathrm{t}) 2$ & $\begin{array}{c}\text { thous. } \\
\text { ha }\end{array}$ & 366,7 & 326,5 & $89 \%$ & 373,2 & 335,2 & $89,82 \%$ & 366,9 & 327,6 & $89,29 \%$ \\
\hline Fire belts and fire lines & $\mathrm{Z}(\mathrm{t}) 3$ & $\begin{array}{c}\text { thous. } \\
\text { ha }\end{array}$ & 293,24 & 327,7 & $112 \%$ & 295,31 & 342,6 & $116,01 \%$ & 296,69 & 488,7 & $164,72 \%$ \\
\hline \multicolumn{12}{|l|}{$\begin{array}{l}\text { Productivity (effectiveness) } \\
\text { indices }\end{array}$} \\
\hline $\begin{array}{l}\text { Volume of average expenses } \\
\text { per } 1 \text { thous. ha of hunting lands } \\
\text { connected with the protection } \\
\text { and reproduction of hunting } \\
\text { animals }\end{array}$ & $\mathrm{E}(\mathrm{t}) 1$ & UAH. & 1740 & 2131 & $122 \%$ & 1810 & 2353 & $130,00 \%$ & 1880 & 2549 & $135,59 \%$ \\
\hline $\begin{array}{l}\text { Change of expenses per } 1 \text { hour of } \\
\text { aerial surveillance }\end{array}$ & $E(t) 2$ & $\begin{array}{l}\mathrm{UAH} / \\
\mathrm{hr} .\end{array}$ & 4000 & 6700 & $168 \%$ & 4452 & 7719 & $173,38 \%$ & 4919 & 8449 & $171,76 \%$ \\
\hline \multicolumn{12}{|l|}{ Quality indices } \\
\hline Survival of forest species & $\mathrm{Q}(\mathrm{t}) 1$ & $\%$ & 80 & 78 & $98 \%$ & 86 & 82 & $95,35 \%$ & 85 & 80 & $94,12 \%$ \\
\hline \multicolumn{12}{|c|}{ Results of calculations } \\
\hline $\begin{array}{l}\text { Integral index of financing in } \\
\text { each year }\end{array}$ & $K(t)$ & & & & 1,050 & & & 1,198 & & & 1,222 \\
\hline $\begin{array}{l}\text { in period including } 1 \& 2 \text { and } 1,2 \\
\& 3 \text { years, etc. }\end{array}$ & $\underline{\mathrm{K}(\mathrm{t})}$ & & & & & & & 1,124 & & & 1,157 \\
\hline $\begin{array}{l}\text { Index of performance in each } \\
\text { year }\end{array}$ & $\mathrm{R}(\mathrm{t})$ & & & & 1,458 & & & 1,438 & & & 1,669 \\
\hline $\begin{array}{l}\text { in period including } 1 \& 2 \text { and } 1,2 \\
\& 3 \text { years, etc. }\end{array}$ & $\underline{\mathrm{R}(\mathrm{t})}$ & & & & & & & 5,829 & & & 13,736 \\
\hline $\begin{array}{l}\text { Level of co-financing in each } \\
\text { year }\end{array}$ & $D(t)$ & & & & 1,631 & & & 2,245 & & & 2,645 \\
\hline $\begin{array}{l}\text { in period including } 1 \& 2 \text { and } 1,2 \\
\& 3 \text { years, etc. }\end{array}$ & $\underline{\mathrm{D}(\mathrm{t})}$ & & & & & & & 1,938 & & & 2,174 \\
\hline
\end{tabular}


Vol. 3, No. 5, 2017

End of Table 1

\begin{tabular}{|c|c|c|c|c|c|c|c|c|c|c|c|}
\hline \multirow[b]{2}{*}{ Name of index } & \multirow[b]{2}{*}{ Symbol } & \multirow[b]{2}{*}{$\mathrm{U} / \mathrm{M}$} & \multicolumn{3}{|c|}{2013} & \multicolumn{3}{|c|}{2014} & \multicolumn{3}{|c|}{2015} \\
\hline & & & planned & actual & $\begin{array}{c}\% \\
\text { executed }\end{array}$ & planned & actual & $\begin{array}{c}\% \\
\text { executed }\end{array}$ & planned & actual & $\begin{array}{c}\% \\
\text { executed }\end{array}$ \\
\hline \multicolumn{12}{|c|}{ Input information } \\
\hline \multicolumn{12}{|l|}{ Financial support } \\
\hline Total & & $\begin{array}{l}\mathrm{mln} \\
\mathrm{UAH}\end{array}$ & 2268,66 & 2703,47 & $119,2 \%$ & 2533,90 & 3077,08 & $121,4 \%$ & 2804,08 & 4235,30 & $151,0 \%$ \\
\hline from state budget & $C(t)$ & $\begin{array}{l}\mathrm{mln} \\
\mathrm{UAH}\end{array}$ & 1043,76 & 562,10 & $53,85 \%$ & 1249,29 & 443,99 & $35,54 \%$ & 1450,41 & 396,11 & $27,31 \%$ \\
\hline $\begin{array}{l}\text { from other sources (own funds of } \\
\text { forest users) }\end{array}$ & $\mathrm{V}(\mathrm{t})$ & $\begin{array}{l}\mathrm{mln} \\
\mathrm{UAH}\end{array}$ & 1224,90 & 2141,37 & $174,82 \%$ & 1284,61 & 2633,10 & $204,97 \%$ & 1353,67 & 3839,19 & $283,61 \%$ \\
\hline \multicolumn{12}{|l|}{ Product indices } \\
\hline $\begin{array}{l}\text { Forestation area (forest planting } \\
\text { and seeding) }\end{array}$ & $\mathrm{Z}(\mathrm{t}) 1$ & $\begin{array}{l}\text { thou } \\
\text { UAH }\end{array}$ & 83,5 & 14,2 & $17,01 \%$ & 95,1 & 5,2 & $5,47 \%$ & 107,7 & 2,4 & $2,23 \%$ \\
\hline $\begin{array}{l}\text { Tending forest species } \\
\text { (area of forests shaping and } \\
\text { rehabilitation) }\end{array}$ & $\mathrm{Z}(\mathrm{t}) 2$ & $\begin{array}{l}\text { thous. } \\
\text { ha }\end{array}$ & 365,4 & 318,7 & $87,22 \%$ & 367,2 & 295,5 & $80,47 \%$ & 368,7 & 305,5 & $82,86 \%$ \\
\hline Fire belts and fire lines & $\mathrm{Z}(\mathrm{t}) 3$ & $\begin{array}{c}\text { thous. } \\
\text { ha }\end{array}$ & 297,45 & 342,7 & $115,21 \%$ & 298,82 & 292,78 & $97,98 \%$ & 299,25 & 351,87 & $117,58 \%$ \\
\hline \multicolumn{12}{|l|}{$\begin{array}{l}\text { Productivity (effectiveness) } \\
\text { indices }\end{array}$} \\
\hline $\begin{array}{l}\text { Volume of average expenses } \\
\text { per } 1 \text { thous. ha of hunting lands } \\
\text { connected with the protection } \\
\text { and reproduction of hunting } \\
\text { animals }\end{array}$ & $\mathrm{E}(\mathrm{t}) 1$ & UAH. & 2010 & 2090 & $103,98 \%$ & 2050 & 3188 & $155,51 \%$ & 2100 & 6246 & $297,43 \%$ \\
\hline $\begin{array}{l}\text { Change of expenses per } 1 \text { hour of } \\
\text { aerial surveillance }\end{array}$ & $E(t) 2$ & $\begin{array}{l}\text { UAH/ } \\
\text { hr. }\end{array}$ & 5,4 & 8,3 & $153,70 \%$ & 5,9 & 22,1 & $374,58 \%$ & 6,5 & 16,6 & $255,38 \%$ \\
\hline \multicolumn{12}{|l|}{ Quality indices } \\
\hline Survival of forest species & $\mathrm{Q}(\mathrm{t}) 1$ & $\%$ & 88 & 85 & $96,59 \%$ & 87 & 85 & $97,70 \%$ & 89 & 86 & $96,63 \%$ \\
\hline \multicolumn{12}{|c|}{ Results of calculations } \\
\hline $\begin{array}{l}\text { Integral index of financing in } \\
\text { each year }\end{array}$ & $\mathrm{K}(\mathrm{t})$ & & & & 1,192 & & & 1,270 & & & 1,657 \\
\hline $\begin{array}{l}\text { in period including } 1 \& 2 \text { and } 1,2 \\
\& 3 \text { years, etc. }\end{array}$ & $\underline{\mathrm{K}(\mathrm{t})}$ & & & & 1,165 & & & 1,186 & & & 1,265 \\
\hline $\begin{array}{l}\text { Index of performance in each } \\
\text { year }\end{array}$ & $\mathrm{R}(\mathrm{t})$ & & & & 1,085 & & & 2,017 & & & 2,990 \\
\hline $\begin{array}{l}\text { in period including } 1 \& 2 \text { and } 1,2 \\
\& 3 \text { years, etc. }\end{array}$ & $\underline{\mathrm{R}(\mathrm{t})}$ & & & & 22,578 & & & 39,540 & & & 65,216 \\
\hline $\begin{array}{l}\text { Level of co-financing in each } \\
\text { year }\end{array}$ & $\mathrm{D}(\mathrm{t})$ & & & & 3,246 & & & 5,768 & & & 10,385 \\
\hline $\begin{array}{l}\text { in period including } 1 \& 2 \text { and } 1,2 \\
\& 3 \text { years, etc. }\end{array}$ & $\underline{\mathrm{D}(\mathrm{t})}$ & & & & 2,442 & & & 3,107 & & & 4,320 \\
\hline
\end{tabular}

Source: compiled and calculated by the author based on the reports of execution of STP "Forests of Ukraine" for 2010-2015

Table 2

Financing of separate indices of the State Target Program "Forests of Ukraine" for 2010-2015

\begin{tabular}{|c|c|c|c|c|c|c|c|c|c|c|}
\hline \multirow[b]{2}{*}{$\begin{array}{c}\text { Product } \\
\text { indices mln } \\
\text { UAH }\end{array}$} & \multirow[b]{2}{*}{$\begin{array}{l}\text { Source of } \\
\text { financing }\end{array}$} & \multicolumn{3}{|c|}{2010} & \multicolumn{3}{|c|}{2011} & \multicolumn{3}{|c|}{2012} \\
\hline & & 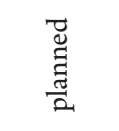 & 胥 & 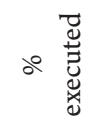 & $\begin{array}{l}\widetilde{\Xi} \\
\mathbb{Z} \\
\text { בี }\end{array}$ & 胥 & $\therefore$ 芯 & 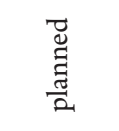 & 苂 & 。菢 \\
\hline \multirow{3}{*}{$\begin{array}{l}\text { Forestation } \\
\text { area }\end{array}$} & SB funds & 106,75 & 90,23 & 84,50 & 231,05 & 96,01 & 41,60 & 299,60 & 79,75 & 26,60 \\
\hline & \begin{tabular}{|l|} 
other \\
sources
\end{tabular} & 13,87 & 20,67 & 149,00 & 14,68 & 20,30 & 138,30 & 16,03 & 20,36 & 127,00 \\
\hline & total & 120,62 & 110,89 & 91,90 & 245,73 & 116,31 & 47,30 & 315,63 & 100,11 & 31,70 \\
\hline \multirow{3}{*}{$\begin{array}{l}\text { Tending } \\
\text { forest } \\
\text { species }\end{array}$} & SB funds & 418,51 & 328,67 & 78,50 & 454,92 & 379,55 & 83,40 & 499,48 & 422,23 & 84,50 \\
\hline & \begin{tabular}{|l} 
other \\
sources
\end{tabular} & 1002,39 & 1280,53 & 127,70 & 1048,78 & 1692,75 & 161,40 & 1106,27 & 1904,96 & 172,20 \\
\hline & total & 1420,90 & 1609,20 & 113,30 & 1503,70 & 2072,30 & 137,80 & 1605,75 & 2327,19 & 144,90 \\
\hline \multirow{3}{*}{$\begin{array}{l}\text { Fire belts } \\
\text { and fire } \\
\text { lines }\end{array}$} & SB funds & 60,32 & 39,51 & 65,50 & 65,76 & 62,90 & 95,70 & 72,87 & 62,38 & 85,60 \\
\hline & \begin{tabular}{|l|}
$\begin{array}{l}\text { other } \\
\text { sources }\end{array}$ \\
\end{tabular} & 39,17 & 46,50 & 118,70 & 39,79 & 61,22 & 153,80 & 42,55 & 69,02 & 162,20 \\
\hline & total & 99,49 & 86,01 & 86,05 & 105,55 & 124,12 & 117,60 & 115,42 & 131,40 & 113,80 \\
\hline
\end{tabular}


End of Table 2

\begin{tabular}{|c|c|c|c|c|c|c|c|c|c|c|c|}
\hline \multirow[b]{2}{*}{$\begin{array}{c}\text { Product } \\
\text { indices mln } \\
\text { UAH }\end{array}$} & \multirow[b]{2}{*}{$\begin{array}{l}\text { Source of } \\
\text { financing }\end{array}$} & \multicolumn{3}{|c|}{2013} & \multicolumn{3}{|c|}{2014} & \multicolumn{3}{|c|}{2015} & \multirow[b]{2}{*}{$\begin{array}{c}\text { Average } \\
\text { level of } \\
\text { financing, } \\
\%\end{array}$} \\
\hline & & 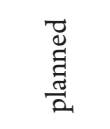 & 芯 & ১e & ד & 胥 & ১e 菢 & 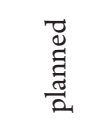 & 芑 & 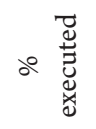 & \\
\hline \multirow{3}{*}{$\begin{array}{l}\text { Forestation } \\
\text { area }\end{array}$} & SB funds & 424,10 & 62,53 & 14,70 & 513,30 & 30,26 & 5,90 & 644,87 & 25,60 & 4,00 & 17,30 \\
\hline & $\begin{array}{l}\text { other } \\
\text { sources }\end{array}$ & 17,10 & 20,73 & 121,20 & 18,07 & 13,29 & 73,60 & 19,51 & 15,63 & 80,10 & 111,80 \\
\hline & total & 441,20 & 83,25 & 18,90 & 531,37 & 43,56 & 8,20 & 664,38 & 41,23 & 6,20 & 21,40 \\
\hline \multirow{3}{*}{$\begin{array}{l}\text { Tending } \\
\text { forest } \\
\text { species }\end{array}$} & SB funds & 539,84 & 429,89 & 79,60 & 584,42 & 377,11 & 64,50 & 635,59 & 324,30 & 51,00 & 72,20 \\
\hline & $\begin{array}{l}\text { other } \\
\text { sources }\end{array}$ & 1162,94 & 2049,32 & 176,20 & 1220,15 & 2540,90 & 208,20 & 1284,89 & 3697,67 & 287,80 & 192,90 \\
\hline & total & 1702,78 & 2479,21 & 145,60 & 1804,57 & 2918,01 & 161,70 & 1920,48 & 4021,97 & 209,40 & 154,90 \\
\hline \multirow{3}{*}{$\begin{array}{l}\text { Fire belts } \\
\text { and fire } \\
\text { lines }\end{array}$} & SB funds & 79,82 & 69,68 & 87,30 & 151,57 & 36,61 & 24,20 & 169,95 & 46,21 & 27,20 & 52,90 \\
\hline & \begin{tabular}{|l|} 
other \\
sources
\end{tabular} & 44,86 & 71,32 & 159,00 & 46,39 & 78,91 & 170,10 & 49,27 & 125,90 & 255,50 & 172,80 \\
\hline & total & 124,68 & 141,00 & 113,10 & 197,96 & 115,52 & 58,40 & 219,22 & 172,11 & 78,50 & 89,30 \\
\hline
\end{tabular}

Source: compiled by the author based on the reports of execution of STP "Forests of Ukraine" for 2010-2015

level of financing in 2010-2015 attained the following figures of the product index by items: "Forestation area (planting and seeding)" - $21.4 \%$ (from the state budget $-17.3 \%$, from other sources of financing $111.8 \%$ ), "Tending forest species (area of forests shaping and rehabilitation)" - $154.9 \%$ (from the state budget - $72.2 \%$, from other sources of financing $192.9 \%$ ), "Fire belts and fire lines" - 89.3\% (from the state budget $-52.9 \%$, from other sources of financing $172.8 \%)$ respectively.

In the entire five years of action, the planned level of budget financing of the Program has not been achieved. In 2010-2011, the Program's activities and tasks were financed from the budget funds by $77 \%$ and in 2014 2015 - by $33 \%$ and $27 \%$ respectively. In the entire period of the Program implementation, average annual index of actual financing from all sources attained 147\%, including 53\% from the state budget, and 206\% from other sources of financing.

The results of the calculations show that the determined indices of the performance of the Program's activities remain to be at a high level $\bar{R}_{2}^{6}=70$.

On the whole, we arrive at the conclusion that in 2010-2015 the forest industry was working steadily, its enterprises fulfilled their tasks. The State Target Program "Forests of Ukraine" for 2010-2015 was being implemented effectively. Regional forestry development programs were elaborated on its basis and approved by the local self-government bodies or regional state administrations.

According to the data of the Ministry of Economic Development on monitoring of implementation of state target programs, the State Target Program "Forests of Ukraine" for 2010-2015 in 2015 was one of the most extensive state target programs of Ukraine implemented through the attraction of funds from other sources in the Program's structure of financing (Ministerstvo ekonomiky Ukrainy, 2016).
Taking into account deductions of taxes, duties, and mandatory payments to the consolidated budget, according to the results of 2010-2015, forestry enterprises of the State Forestry Agency returned to the state more than $3 \mathrm{UAH}$ for each hryvnia received from the state (Fig. 1). Enterprises of the State Forestry Agency spent 5 times more of their own funds for the implementation of the Program than they had received from the State Budget.

The main indices that can be used to assess effectiveness of implementation of the State Target Program "Forests of Ukraine" for 2010-2015 are indices that provide an opportunity for the identification of general trends in forest management, quantitative and qualitative changes in the forest reserves of Ukraine: forest cover, changes in total area of forest reserves, area of timber sites and area

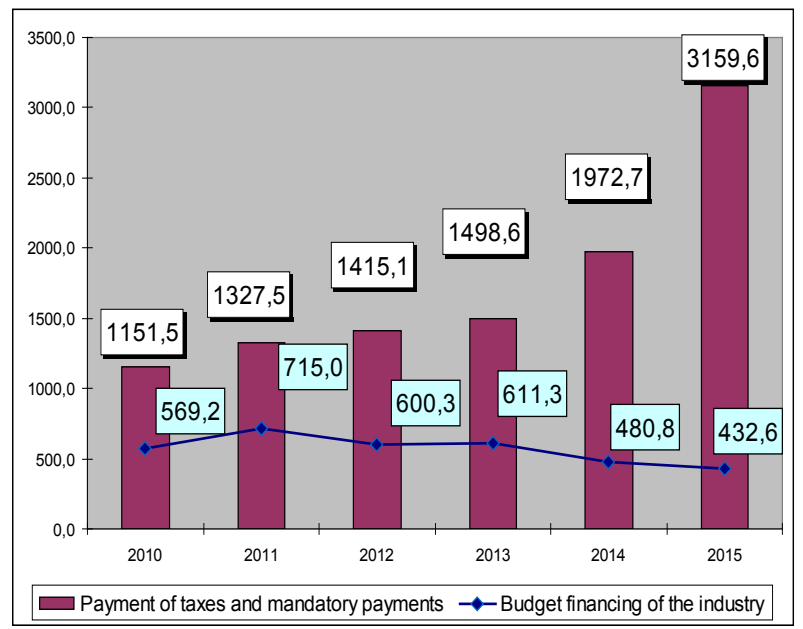

Fig. 1. Payment of taxes and mandatory payments by forestry enterprises of the State Forestry Agency and budget financing of the industry for the implementation of the State Target Program "Forests of Ukraine" for 2010-2015, mln UAH

Source: compiled by the author based on the reports of execution of STP "Forests of Ukraine" for 2010-2015 
of lands covered with forest vegetation, total growing stock reserves, reserves of mature and overmature plantations, average growing stock increment, species composition of forests per 1 hectare of area covered with forest vegetation, distribution of forest reserves by the departmental affiliation, distribution of forest areas by categories depending on the main functions they perform, etc.

These indices can be obtained only by taking the state inventory of forests (Lisovyi Kodeks, Verkhovna Rada Ukrainy, 1994) and after obtaining consolidated documentation from the state forest cadastre. The last such inventory (summary of data on the natural, economic status and legal regime of the forest reserves) was taken as of 01.01.2011, which made it possible to identify positive changes in the forest reserves of Ukraine, namely:

- increase in total area of forests and improvement of forest cover in Ukraine (15,9\%);

- increase in the share of forest areas performing predominantly ecological and social functions;

- increase in the area of mature and maturing growing stock that allows increasing gradually the allowable cutting in forests fit for exploitation;

- increase in total and average reserves of growing stock per 1 hectare;

- increase in the area of economically valuable species.

It was planned that in the result of the implementation of the Program, the area of forests in Ukraine will grow by almost 0.5 million hectares and forest cover percentage will be $16.1 \%$ by 2015 .

However, the state forest inventory that was to be taken in 2015 as envisaged by the normative-legal acts and by the Program has not been taken because of the absence of allocation in the state budget for these purposes.

In the future, the next state inventory of forests of Ukraine that in accordance with paragraph 8 of the Procedure for keeping the state forest cadastre and forest inventory, approved by resolution of the Cabinet of Ministers of Ukraine № 848 of 29.06.2007, must be taken once every five years, and then there will be obtained all the necessary indices, by which, comparing them with the indices of the state inventory as of 01.01.2011, it will be possible to assess in detail effectiveness of implementation of the State Target Program "Forests of Ukraine" for 2010-2015.

\section{Conclusions}

Proceeding from the results of the analysis made, it can be stated that the main condition for the effective implementation of state target natural environmental protection programs is their even financing throughout the entire period of their implementation both from the budgetary and from extrabudgetary funds with their uninterrupted control at all stages of implementation.
Application of the proposed methodological approach to the construction of effective indices of implementation of programs provides the possibility to determine parameters of priority ranking of budget financing of state target programs for the next year on the basis of calculation of the comprehensive assessment of the actual process of implementation of programs in progress taking into account correspondence of the achieved program results to the established priorities of socio-economic development.

Application of multidimensional indices of the product, quality and effectiveness in the process of determining the performance of programs that, according to the developed algorithm, are calculated by many parameters, makes it possible to estimate the total impact of various effects by constructing a unique for each program quantitatively defined integral parameter - the performance index.

This is why we believe that the following proposals will contribute to the improvement of the process of elaboration of state target programs for the protection of the natural environment in Ukraine:

1. Promotion of innovation activities and research works in the sphere of monitoring the state of natural environment, including: providing sufficient state support for the research programs for the assessment of natural resources potential of Ukraine, elaboration and introduction of the system of indices for the balanced development and spatial planning methods, impact of factors of the natural environment on health of the population and demographic tendencies; conducting fundamental research with the formation of a new ideology of life of the Ukrainian society, aimed at ecologization of the economy, manufacture, consumption, policy, education; conducting economic assessment of the cost of natural resources; promotion of scientific research in the field of effective teaching methods, tools for the assessment of balanced development, formation of attitudes towards life and values, etc.

2. Increasing the degree of public involvement in the preparation of state projects for the natural environmental protection.

3. Ensuring a transparent information support and access to reports on the execution of state programs in the sphere of protection of natural environment.

4. Establishment by the developer of state natural environmental protection programs of stable two-way communication and collaboration with the public environmental organizations and active population.

5. Keeping population by the public contracting customers of state environmental protection programs constantly informed about the matters pertaining to the solution of local and national environmental problems and to the process of transition to a balanced development with the active involvement of mass media. 
6. Improving the effectiveness of management and professionalism of executors of the state programs in the sphere of natural environmental protection, including: ensuring proper improvement of qualification of persons, authorized to perform state functions, in the matters of balanced development, particularly, in the matters of balanced planning; support in decision-making in the use of natural resources, in the implementation of investment projects that have an effect on the quality of life of people, only in a transparent manner with the involvement of interested persons; introduction of clear mechanisms for the accountability of citizens at all levels; promoting a fuller integration at the vertical level between the local and state power authorities in decision-making.

The use of the proposed calculation of the integral performance indices creates the basis for the application of the system of rating of state target environment protection programs as an effective tool for the redistribution of budget funds for the execution of more effective programs and projects thus improving the effectiveness of the use of budget resources.

\section{References:}

Danylyshyn, B. M. (2008). Naukovi narysy z ekonomiky pryrodokorystuvannia [Scientific essays on economy of the use of natural resources]. Kyiv: RVPS Ukrainy NAN Ukrainy. (in Ukraine)

Faichuk, O. V., Faichuk, O. M., Voytsekhivska, V. V. (2015). Efektyvne finansuvannia derzhavnykh tsilovykh ekolohichnykh prohram [Effective financing of state target ecological programs]. Economist, 7, pp. 31-33.

Heiets, V. M. (2008). Derzhavni tsilovi prohramy ta uporiadkuvannia prohramnoho protsesu v biudzhetnii sferi [State target programs and streamlining the program process in the budget sphere]. Kyiv: Naukova Dumka. (in Ukraine) Hryniv, L. S. (2010). Rehionalni tsilovi prohramy [Regional target programs]. Lviv: Lvivskyi natsionalnyi universytet imeni Ivana Franka. (in Ukraine)

Lisovyi Kodeks No. 3852-XII of January 21 (1994). [Forest Code]. (Verkhovna Rada Ukrainy). Ofitsiinyi sait Verkhovnoi Rady Ukrainy. Retrieved from: http://zakon4.rada.gov.ua/laws/show/3852-12 (accessed 15 December 2017).

Melnyk, L. H. (2003). Ekolohichna ekonomika [Ecological economy]. Sumy: Universytetska knyha. (in Ukraine)

Moshchytska, T. O. (2010). Derzhavni tsilovi prohramy yak diievyi instrument stymuliuvannia rozvytku ekonomiky [State target programs as an effective tool for stimulation of economic development]. Problemy ekonomiky, 3, pp. 28-33.

Nakaz pro metodychni rekomendatsii shchodo provedennia otsinky ekonomichnoi i sotsialnoi efektyvnosti vykonannia derzhavnykh tsilovykh prohram No.742 ofJune 24(2010). [Order on methodological recommendations for assessment of economic and social effectiveness of implementation of the state target programs]. (Ministerstvo ekonomiky Ukrainy). Ofitsiinyi sait Ministerstva ekonomiky Ukrainy. Retrieved from: http://www.me.gov.ua (accessed 07 December 2017).

Postanova pro derzhavnu tsilovu ekolohichnu prohramu provedennia monitorynhu navkolyshnoho pryrodnoho seredovyshcha No. 1376 of December 5 (2007). [Resolution on the state target ecological program of monitoring natural environment]. (Kabinet Ministriv Ukrainy). Ofitsiinyi sait Kabinetu Ministriv Ukrainy. Retrieved from: http://zakon2.rada.gov.ua/laws/show/1376-2007-\%D0\%BF (accessed 27 November 2017).

Postanova pro derzhavnu tsilovu ekolohichnu prohramu rozvytku Krymu na 2011-2015 rr. No. 539 of May 25 (2011). [Resolution on the state target ecological program for the development of the Crimea for 2011-2015]. (Kabinet MinistrivUkrainy). Ofitsinyi sait Kabinetu MinistrivUkrainy. Retrieved from: http://zakon2.rada.gov.ua/ laws/show/539-2011-\%D0\%BF (accessed 29 November 2017).

Postanova pro derzhavnu tsilovu prohramu Lisy Ukrainy na 2010-2015 rr. No. 977 of September 16 (2009). [Resolution on the State Target Program «Forests of Ukraine» for 2010-2015]. (Kabinet Ministriv Ukrainy). Ofitsiinyi sait Kabinetu Ministriv Ukrainy. Retrieved from: http://zakon2.rada.gov.ua/laws/show/977-2009\%D0\%BF (accessed 28 November 2017).

Stan vykonannia derzhavnykh tsilovykh prohram u 2015 rotsi. (2016). [State of implementation of state target programs in 2015]. (Ministerstvo ekonomiky Ukrainy). Ofitsiinyi sait Ministerstva ekonomiky Ukrainy. Retrieved from: https://issuu.com/mineconomdev/docs/ (accessed 07 December 2017).

Yakushenko, L. M., Yatsenko, L. D. (2015). Shchodo napriamkiv pidvyshchennia efektyvnosti vykonannia zahalnoderzhavnykh prohram u pryrodookhoronnii sferi [On the ways of increasing effectiveness of implementation of the national programs in the sphere of natural environment protection]. Informatsiino-analitychna dovidka. Retrieved from: http://www.niss.gov.ua/articles/537/ (accessed 02 December 2017).

Yatsenko, L. D. (2015). Shchodo otsinky vyklykiv natsionalnii bezpetsi v ekolohichnii sferi [On the assessment of challenges to national security in the ecological sphere]. Analitychna zapyska. Retrieved from: http://www.niss.gov. ua/articles/1150/ (accessed 14 December 2017).

Zakon pro zahalnoderzhavnu prohramu formuvannia natsionalnoi ekolohichnoi merezhi Ukrainy na 2000-2015 rr. No. 1989-III of September 21 (2000). [The Law on the national program of formation of the national ecological network of Ukraine for 2000-2015]. (Verkhovna Rada Ukrainy). Ofitsiinyi sait Verkhovnoi Rady Ukrainy. Retrieved from: http://zakon2.trail.gov.ua/laws/show/1989-14 (accessed 05 December 2017).

Zakon pro zahalnoderzhavnu prohramu rozvytku mineralno-syrovynnoi bazy Ukrainy na period do 2030 roku No. 268-VI of April 21 (2011). [The Law on the national program of development of the mineral-raw material base of 
Ukraine in the period up to 2030]. (Verkhovna Rada Ukrainy). Ofitsiinyi sait Verkhovnoi Rady Ukrainy. Retrieved from: http://zakon0.rada.gov.ua/laws/show/3268-17 (accessed 28 November 2017).

Zakon pro zahalnoderzhavnu tsilovu ekolohichnu prohramu povodzhennia z radioaktyvnymy vidkhodamy No. 516-VI of September 17 (2008). [The Law on the national target ecological program of radioactive waste materials management]. (Verkhovna Rada Ukrainy). Ofitsinyi sait Verkhovnoi Rady Ukrainy. Retrieved from: http://zakon0.rada.gov.ua/laws/show/516-17 (accessed 29 November 2017).

Zakon pro zahalnoderzhavnu tsilovu prohramu Pytna voda Ukrainy na 2011-2020 rr. No. 3933-VI of October 20 (2011). [The Law on the National Target Program Drinking Water of Ukraine for 2011-2020]. (Verkhovna Rada Ukrainy). Ofitsiinyi sait Verkhovnoi Rady Ukrainy. Retrieved from: http://zakon2.rada.gov.ua/laws show/245515 (accessed 25 November 2017).

Zakon pro zahalnoderzhavnu tsilovu prohramu rozvytku vodnoho hospodarstva ta ekolohichnoho ozdorovlennia baseinu richky Dnipra na period do 2021 roku No. 4836-VI of May 24 (2012). [The Law on the national target program for the development of water economy and ecological rehabilitation of the Dnipro river basin in the period up till 2021]. (Verkhovna Rada Ukrainy). Ofitsiinyi sait Verkhovnoi Rady Ukrainy. Retrieved from: http://zakon3.rada.gov.ua/laws/show/4836-17 (accessed 29 November 2017).

Zarzhytskyi, O. S. (2012). Aktualni problemy pravovoho zabezpechennia ekolohichnoi polityky Ukrainy (teoretychni aspekty) [Current problems of legal support of ecological policy of Ukraine (theoretical aspects)]. Donetsk: Natsionalnyi hirnychyi universytet. (in Ukraine). 